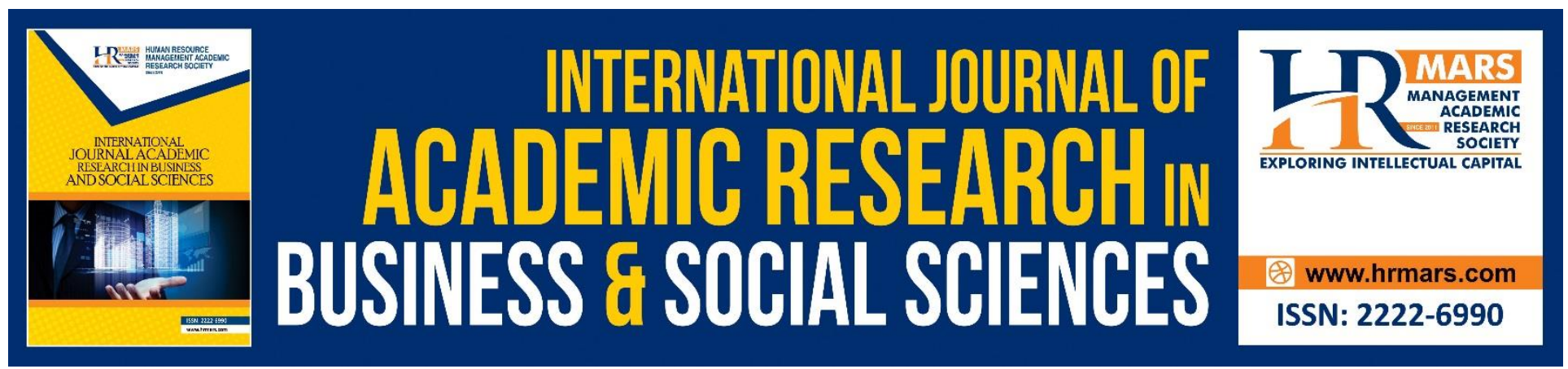

\title{
Analysis of the Concept of Fatwa Uniformity according Mura'ah Al-Khilaf Method
}

Fathullah Asni

To Link this Article: http://dx.doi.org/10.6007/IJARBSS/v8-i7/4331

DOI: $\quad 10.6007 /$ IJARBSS/v8-i7/4331

Received: 24 May 2018, Revised: 22 July 2018, Accepted: 29 July 2018

Published Online: 30 July 2018

In-Text Citation: (Asni, 2018)

To Cite this Article: Asni, F. (2018). Analysis of the Concept of Fatwa Uniformity according Mura'ah Al-Khilaf Method. International Journal of Academic Research in Business and Social Sciences, 8(7), 156-164.

Copyright: (C) 2018 The Author(s)

Published by Human Resource Management Academic Research Society (www.hrmars.com)

This article is published under the Creative Commons Attribution (CC BY 4.0) license. Anyone may reproduce, distribute, translate and create derivative works of this article (for both commercial and non-commercial purposes), subject to full attribution to the original publication and authors. The full terms of this license may be seen

at: http://creativecommons.org/licences/by/4.0/legalcode

Vol. 8, No. 7, July 2018, Pg. 156 - 164

http://hrmars.com/index.php/pages/detail/IJARBSS

JOURNAL HOMEPAGE

Full Terms \& Conditions of access and use can be found at http://hrmars.com/index.php/pages/detail/publication-ethics 


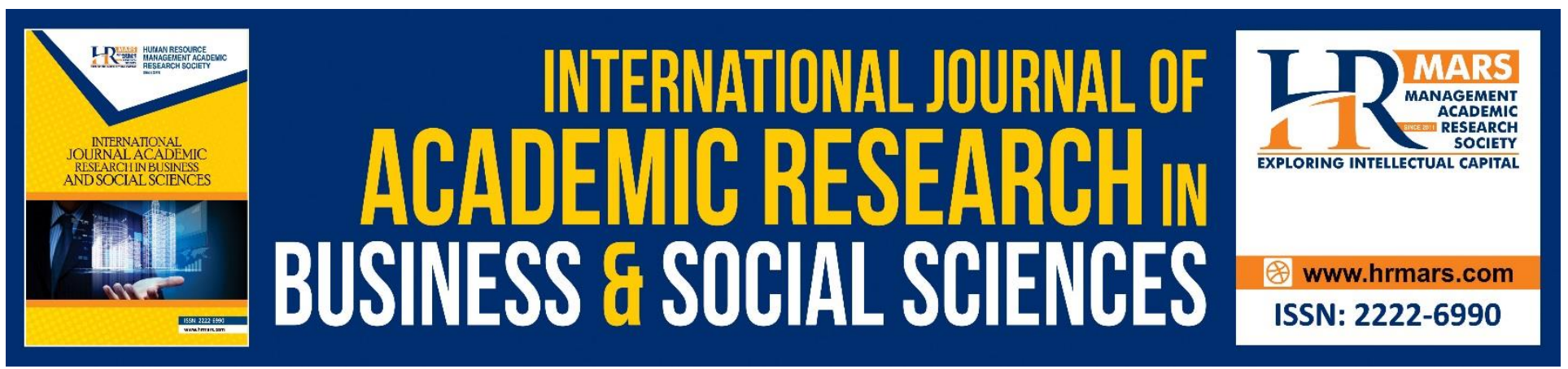

\title{
Analysis of the Concept of Fatwa Uniformity according Mura'ah Al-Khilaf Method
}

\author{
Fathullah Asni \\ School of Humanities, Universiti Sains Malaysia \\ Email: fathasni90@gmail.com
}

\begin{abstract}
The purpose of this paper is to study the concept of fatwa uniformity based on the debate on al-fiqh methods. This study is based on the problem of the existence of fatwa disputes between mufti because it is supported by the figh method which means "ijtihad cannot cancel other ijtihad". This method shows that anyone who has the skills to issue a fatwa, has the right to issue a fatwa. Although now in every Muslim country there has been an official mufti organised by the fatwa institution. These fatwa differences can have negative implications from the perspective of fatwa governance management because there is no coordination and can bring confusion to civil society that cannot dissolve due to fatwa disputes among muftis. The methodology of this study is qualitative in which the data are collected through a library research method by studying the books of al-figh. The findings show that there is a fiqh method known as mura'ah al-khilaf which gives space to mufti to celebrate the other mufti's opinions although it is entitled to study with his ijtihad. This method can provide an opportunity for the official mufti to issue a fatwa and be followed and celebrated by qualified local scholars to issue a fatwa. It also avoids the release of some of the fatwa from the authoritative parties and others which may have the effect of the fatwa difference.
\end{abstract}

Keywords: Mura'ah al-Khilaf, Fatwa Differences, Fatwa Uniformity, Mufti, Ijtihad

\section{Introduction}

This study is based on the problem of fatwa differences between the muftis. The issue of fatwa differences can confuse the civil society who cannot understand the difference in opinion in the fiqh and does not show good governance in the fatwa institution when a conflict happened in the fatwa law. Also, nowadays almost every Muslim nation, institutionalised fatwa requires a uniform administrative method to be well managed and useful to the public (Asni 2016a).

Based on previous studies, there are several studies that support the uniformity of fatwa from various angles either in terms of administration and enforcement as is done by Nasohah et al. (2012), Mohamad et al. (2014), Mamat et al. (2013) and Asni et al. (2017c). While thinking about the uniformity of fatwa and law based on Ibn al-Muqaffa' and al-Syatibi's thought has been reviewed by Sulong (2014) and Asni (2017a). The study of this thinking is to expose specific individual efforts in the standardisation effort from the legal point of view and the method of legal (hukm) production. 
INTERNATIONAL JOURNAL OF ACADEMIC RESEARCH IN BUSINESS AND SOCIAL SCIENCES Vol. 8, No. 7, July 2018, E-ISSN: 2222-6990 @ 2018 HRMARS

From a case study point, it was found that Asni et al. (2016b/2017b) has proposed the standardisation of fatwa on fatwas involving the issue of wasiat wajibah and waqf.

However, the existence of fatwa and ijtihad differences is supported by the figh method which means, "ljtihad cannot cancel other ijtihad". This method gives the impression that anyone who has qualified can issue a fatwa even though there is a particular mufti that issued a fatwa from the official institution that manages the fatwa affairs in which the government appoints it, i.e. ulil amri at the national level (al-Yusof $1430 \mathrm{H}$ ).

Furthermore, fatwa differences are also supported by the Mazhab al-Syafi'i which states that mufti or mujtahid cannot follow the ijtihad issued by other mujtahids. This is because mufti or mujtahid should play a role in researching and conducting the fatwa production process (al-Ghazali 1997). Freedom in fatwa production can lead to fatwa differences even in the same issue. Hence, the beginning of this issue creates the question that is it not possible to standardise the fatwa according to the fiqh debate? Therefore, this study was conducted to examine the concept of fatwa uniformisation.

\section{The Philosophy of Fatwa and ljtihad}

Fatwa and ijtihad is a legal istinbat methodology discussed in Usul al-Fiqh knowledge. The word fatwa and ijtihad has its meaning. A fatwa is an opinion or a decision whether personal or produced by a group of mujtahid on an Islamic law derived from two primary sources of Islamic law, which are alQuran and al-Sunnah. Each fatwa production is the personal initiative or a request from the public. In this case, the mufti can also act proactively in dealing with a question by ordered the investigation of certain law, although there are no fatwa applications as a preparatory step (Khudzri 2006). The accuracy of a fatwa is highly dependent on the proofing method used and its alignment with the maqasid al-shari'a. According to al-Ghazali (1997), fatwa mufti tasks are undertaken by the mujtahid who can perform ijtihad and istinbat law.

Whereas the purpose of ijtihad is defined by al-Shaukani (1999) as mobilising capabilities to get the comprehensive Islamic law following the right istinbat methods (taking the evidence). While al-Amidi (2003) defines ijtihad as to devote all capabilities to understand the Islamic law that is speculative or uncertain (zanni) until feels unable to find more than that. Based on this, al-Ghazali (1997) makes restrictions all capabilities as part of the definition of perfect ijtihad (al-ijtihad al-tam). Hence, ijtihad can be understood as a mujtahid effort whose maximise all efforts mentally and intellectuals to study and understand Islamic law. It is an effort that eventually resulted in the finding or decision of ijtihad, which was later called a fatwa. Thus, the fatwa is the result of ijtihad.

Therefore, the mufti and mujtahid are generally the same, only different regarding the causes of the fatwa issued with a specific purpose like to answer a question or solve a problem that has already occurred, while ijtihad is not bound by those terms (al-Qasimi 1406H). Based on this, some scholars do not distinguish between the mufti and the mujtahid because each refers to the party entitled to issue Islamic law (al-Shatibi 1997). A fatwa decided by a mujtahid is to show the achievements of Islamic scholars that sometimes is same as the views of another mujtahid, and sometimes different. Islam recognises intellectual mujtahid results until that ijtihad and fatwa is binding to the mujtahid, and another mujtahid cannot cancel that ijtihad or fatwa, although not bound to comply. 
INTERNATIONAL JOURNAL OF ACADEMIC RESEARCH IN BUSINESS AND SOCIAL SCIENCES Vol. 8, No. 7, July 2018, E-ISSN: 2222-6990 @ 2018 HRMARS

\section{Adab al-Khilaf in Giving Fatwa}

Based on the recognition of Islam because of the differences between the mujtahid and Mufti, then the fuqaha' (jurists) should be open-minded on an issue that occurs disagreement (khilaf). According to the Maliki madhhab, manner or method in celebrating differences (mura'ah al-khilaf) is to respect the knowledge, the effort and the thoughts of a mujtahid (Musa n.d.). In this case, 'al-mura' ah' means preservation (al-hifz) and the attitude of compromise (al-rifq) (Manzur n.d.), while the word al-khilaf regarding language is no consensus or agreement and disagreement something (Manzur n.d.). The meaning here is there is no existing consensus view among people who are knowledgeable on the issues where everyone believes in his or her opinions (Shaqrun 2002).

There are various manners to celebrate in mujtahid different views. Among them, according to al-Risa' (1993) is emphasised arguments and opinions another mujtahid than his argument and opinion, in a situation where an opinion produced was found to have stronger proof (dalil), compatibility issues with the current situation. While Ibn Abd al-Salam explains it as giving every one of its legal proofs, emphasising differ opinions when the condition is more appropriate (al-Manjur n.d.). Whereas according to Ibn 'Urfah, celebrate khilaf by adopting the proofs of the customs practised and in other circumstances, to use other appropriate proofs and the prevailing situation (alRisa' 1993). The manners in respects another mujtahid fatwa is based on the strength of arguments, methods and conditions over the interests of the public. In other words, the contrary evidence is a priority if there is a fatwa that could bring harm to religion and social (al-Ansari 2010).

According to al-Fahri (2001), manners and methods of mura'ah al-khilaf are to achieve the shara' objectives by practising with arguments according to the circumstances to achieve Maqasid alShari'a. A mujtahid is allowed to get out of the madhhab group and his opinion by adhering to the others opinions who are more appropriate (rajih) based on the arguments discussed (Jaddiyyah 2010). As a result, mura'ah al-khilaf can unite Muslims through respect for the views of the other mujtahid, with this can bridge the gap between mazhab, narrowing the difference (khilaf) and eliminate the difficulties of the Muslim. According to al-Nadwi (2009), this method is significant because its effect can cause a sense of caution in religious, cultivate love and bring legitimate public interest. Commenting on this, Ibn Mas'ud said that the dispute is a bad thing. Mura'ah al-khilaf concept is such a mujtahid preference (istihsan) where a mujtahid give priority on an argument of the other mujtahid (which is hidden) compared to his own opinion (which is explicit) as closer to the goal of Islamic law. Mura'ah al-khilaf principle is also in line with saddu al-dhara'i' to avoid elements that could lead to damage (al-Qurtubi n.d.).

Al-Shatibi (1997) rationalises it as a method of achieving public interest (maslahah) and eliminate damage (mafsadah). Assessment of these benefits (al-aslah) is measured by the impact or implications of a fatwa and this is consistent with the theory of ma'alat al-af'al which view to the completion of the act/action either parallel with Islamic purpose or not (al-Shatibi 1997; al-Shikh 2002). According to al-Husayn (2009), ma'alat al-af'al is calculating whether the law decided is meeting the requirements of Islamic law, and is compatible with the purpose of the practice was sanctioned. The method mura'ah al-khilaf not only look at the evidence referred to, but also look at the impact that parallels with maqasid shari'a (Shaqrun 2002). The implementation of istinbat method will indirectly lead to talfiq where a mujtahid do ijtihad tarjihi by selecting a more right (arjah) opinion. In this case, the mujtahid not only takes the opinion of his madhhab only, but also can take from any point of view another madhhab who have right decision (Malik 2005).

In celebrating the differences of opinion, the concept is to achieve maqasid shari'a, and match the maqasid with the current reality (waqi'), and priority (al-aulawiyyat) to be carried out at that time. 
INTERNATIONAL JOURNAL OF ACADEMIC RESEARCH IN BUSINESS AND SOCIAL SCIENCES Vol. 8, No. 7, July 2018, E-ISSN: 2222-6990 @ 2018 HRMARS

Mujtahid in attributing the problem based on the suitability of current, distinguishing between the main from another major, and can give proper consideration by the arbitral jurisprudence (almuwazanat) (al-Qaradawi 1996). Thus, mura'ah al-khilaf also emphasises the similarity 'illah law and wisdom (hikmah) that in line with the objectives of Islamic law (al-Juwaini 1997). Following the context of jurisprudence that will change with the changing times, places and customs ('urf), then the element fiqh al-waqi' help mujtahid in celebrating differences. The change in time will lead to changes in needs and preferences that can alter human necessaries (daruriyyah), needs (hajiyyah) and beauty (tahsiniyyah) (Zaidan 2003). However, this flexibility is not up to something 'urf is contrary to Islamic law (al-Ghazali 1997). It must lead to the opinion or right custom recognised by Islamic law (al-Zarqa' 1995).

\section{Uniformity of Fatwa in the midst of al-Khilaf}

History shows that the born of madhhab is mujtahid's effort to understand Islamic law, rather than the purpose of different views. With limited Islamic legislation resources, Muslims should be united in their understanding (fiqh) on the nas and apply it in actions and practices. Thus, madhhab fanaticism should be avoided as it not only leads to disunity, even causing administration instability and hostility (al-Dusuqi n.d.; al-Humawi n.d.; Kathir 1988). Differences and extreme in the madhhab can cause harm to Islam and Muslims.

Consolidation efforts and celebrate the differences of opinion have been committed by all parties that were started since Companions (sahabah) era. For example, Ibn Mas'ud who have chosen to follow ijtihad 'Uthman (Caliph at that time) and leave his ijtihad (Abu Dawud 2009). Similarly, 'Umar al-Khattab, who said he was ashamed of Allah, if different views with Abu Bakr, and in that case 'Umar gave priority to Abu Bakr's view (al-Qayyim 1973). In this case, respect the views of those who are more knowledgeable and the leader (authoritative) is one of the effective methods for consolidation. According to al-Sha'bi, some Companions are celebrating Companions view that is more knowledgeable at the same time such as Abdullah bin Mas'ud celebrate opinion of 'Umar bin al-Khattab, Abu Musa 'Ali and Zaid celebrate Ubay ibn Ka'ab opinion even though they all have their own opinion (al-Shaukani 1396H).

The same spirit prevailed in the time tabi'in and tabi' tabi'in when the views of the most authoritative are followed and official fatwa to avoid khilaf. Therefore the Abbasid era, Secretary of Country, 'Abd Allah ibn al-Muqaffa' suggested to Caliph Abu Ja'far al-Mansur to lift the Kitab alMuwatta' of Imam Malik to become mainstream government opinion and his ijtihad enacted into a uniform law. However, this proposal was not accepted by Imam Malik (al-Anbari 1987; Sulong 2014; al-Muhamid 2001). Likewise desirable by the Caliph al-Mahdi and the Caliph al-Rashid to make Maliki Madhhab opinions as the official reference (Musa 1983; al-Dhahabi 1985; al-Asbahani 1996). Lastly, this proposal was accepted by Abu Yusuf from the Hanafi Madhhab when Harun al-Rashid Government had appointed him as chief justice and make the book al-Kharraj as a reference (Sulong 2014). After that, many of the fatwas and writings of Islamic jurisprudence become a reference and laws in countries such as the Kingdom of Abbasid which rule al-Mawardi wrote the book al-Ahkam al-Sultaniyyah to be the official reference (al-Mawardi 1986; al-Muhamid 2001). This standardisation not only in the form of a reference source, even to the madhhab. For example, the Government Khadive Muhammad 'Ali Pasha, who ruled the Ottoman government has issued an order that only the judge or the Hanafi mufti only allowed to issue fatwas or legal decisions in cases related to Islamic law (Sulong 2014). 
INTERNATIONAL JOURNAL OF ACADEMIC RESEARCH IN BUSINESS AND SOCIAL SCIENCES Vol. 8, No. 7, July 2018, E-ISSN: 2222-6990 @ 2018 HRMARS

Standardisation efforts and creating a single opinion of the fatwa only to be practised in a country does not end there. In this case, jurists and administrators also must understand the istinbat methods of Islamic law proper and uniform so that the ijtihad will lead to the same result. Thus, 'Abd al-Rahman bin Mahdi had proposed to Imam Shafi'i to write a book which describes the production methodology of law jurisprudence based on Islamic arguments which are al-Quran and hadith, and the use of evidence that is qat'i, zanni, nasikh and mansukh. This article aims to outline the procedure to be uniform about Islamic law where the law result achieved will be uniform and consistent (Sulong 2014). Besides, standardisation is also encouraged by the imam of the four madhhabs in another word where all of them ask to give priority to the strength of the proof when practising with the law and leave their opinion if weak (marjuh) (al-Shahid 2005).

In this context, the fatwa uniformity can happen by focusing on the strengths of proofs and achievements of benefit (maslahah) and Maqasid, regardless madhhab background. This is the opinion of 'Abd al-'Aziz bin Muhammad bin Ibrahim Ali al-Shikh, Salih bin Ghasin, Rashid bin Khunain (al-Muhamid 2001), al-Muraghi (2011), Abu Zahrah (al-Muhamid 2001), 'Ali al-khafif (al-Muhamid 2001), Muhammad Makhluf (al-Muhamid 2001), 'Abd al-Wahhab Hafiz (al-Muhamid 2001), Muhammad Zaki 'Abd al-Barr (al-Muhamid 2001), al-Qaradawi (2011), al-'Attar (1993), al-Zarqa' (1999), al-Zuhaili (2014), al-Tha'alabi (2012) and al-Mawdudi (al-Muhamid 2001). They back up this opinion with maslahah arguments in which it can ease the qadi and the Muslim community in the Islamic law, reduce errors when to adjudicate, uniting the country fatwa by taking the most rajih law and avoid the negative consequences of the dispute (al-'Attar 1993). The use of this maslahah evidence precisely because the absence of prohibit evidence (mulghah) or assign (mu'tabarah), even very advantageous to be applied in al-siyasah al-shar'iyyah where the administrator has set the same laws that facilitate public and compulsory to do so (al-Muhamid 2001).

Fixing to a fatwa decision that uniform is one of the government's jurisdictions under the principles of al-siyasah al-shar'iyyah. When a leader has set a law, then it is compulsory to do so and obedient to the law. Obedience is based on the word of Allah S.W.T, that is, "O you who have believed, obey Allah and obey the Messenger and those in authority among you (Al-Nisa': 59)." Based on this verse, Allah S.W.T commands to obey wali al-amr whether it is pledged to the government or the scholars. Thus, the jurists set the law to become legislation, while the government enforce the law and must be obeyed (al-Muhamid 2001). Also, it is also supported by the word of Allah S.W.T which means, "discuss with them in the affair (Ali-Imran: 159)." This is because, a discussion will avoid disputes, which is prohibited and a consensus can be achieved (al-Muhamid 2001).

Likewise, set by the Sunnah of the Prophet S.A.W about obey the leader as the words of the Prophet S.A.W which mean, "hear and obey even if the slaves of Habshi rule over you" (al-Bukhari $1422 \mathrm{H}$ ). In this case, if khilaf happened, it is required for other jurists (fuqaha') in the country (mura'ah al-khilaf) to follow the official fatwa that had been decided even in contravention of his ijtihad (Ibn 'Abidin 1386H). At least, the attitude of celebrating the official fatwa will produce a uniform implementation of the law, so as to create a fair environment for Islamic purpose which as Allah S.W.T which means, "Indeed, Allah commands you to render trusts to whom they are due and when you judge between people to judge with justice (Al-Nisa': 58)." Clearly, whatever the medium (wasilah), which can lead to welfare, justice and parallel with the objectives of the shari'a is required to be implemented as a method of jurisprudence mentioned, "something that compulsorily is not perfect but with it then it will also be compulsory" (al-Subki 1991).

Hence, standardisation opinion can be done with reconciliation and then ensure the enforcement and administration of Islamic law can be carried out fairly (El-Muhammady 1992). 
INTERNATIONAL JOURNAL OF ACADEMIC RESEARCH IN BUSINESS AND SOCIAL SCIENCES

Vol. 8, No. 7, July 2018, E-ISSN: 2222-6990 @ 2018 HRMARS

Indirectly, rigidity to a madhhab not too restrict the members of ijtihad until reduced taqlid domination and the extreme attitude to the fatwa their madhhab only (al-Qaradawi 2004). Thus, the spirit of openness and reformism approach to limit taqlid bonding excessively, especially in the methodology issuance of a fatwa should be owned by the mujtahid nowadays to produce uniform fatwa, balanced and fair to enforce on society and the country (Naemah 2003).

\section{Conclusion}

Standardisation fatwa and ijtihad union decision is something that is important because it highlights the teachings of justice and equality in Islam. Thus, efforts istinbat and ijtihad should be done systematically, consistently and in compliance with the standards of knowledge epistemology either from the point of passage proof or scholarly of mujtahid and the Mufti. It also has manners so that jurists underlined the manners in different opinion when to give a fatwa (mura'ah al-khilaf). Right fatwa (rajih) is to solve the problem, bring benefit, or avoid harm and does not cause other problems later. By its meaning, a fatwa should be uniform and align because the benefits and objectives of the shari'a are one, equal and similar, moreover when it is practised at the same time.

\section{Corresponding Author}

\section{Fathullah Asni}

School of Humanities, Universiti Sains Malaysia, 11800 Pulau Pinang, Malaysia

Email: fathasni90@gmail.com

\section{References}

Abu Dawud, S. S. (2009). Sunan Abu Dawud. Beirut: Dar al-Risalah al-'Ilmiyyah Al-'Attar, A. T. (1993). Tatbiq al-Shari'ah al-Islamiyyah fi al-'Alam al-Islami. Qaherah: Dar al-Fadilah Al-Amidi, S. M. (2003). Muntaha al-Sul fi 'Ilm al-Usul. Beirut: Dar al-Kutub al-'Ilmiyyah

Al-Anbari, A. R. A. (1987). Mansib Qadi al-Qudah fi al-Dawlah al-'Abbasiyyah. Beirut: al-Dar al'Arabiyyah li al-Mawsu'ah

Al-Ansari, F. (2010). al-Mustalah al-Usuli 'Inda al-Shstibi. Qaherah: Dar al-Salam Al-Asbahani, A. A. M. (1996). Hilyah al-Auliya' wa Tabaqat al-Asfiya'. Beirut: Dar al-Fikr Al-Bukhari, M. I. (1422H). Sahih al-Bukhari. Jiddah: Dar Tauq al-Najah

Al-Dhahabi, S. M. A. (1985). Siyar A'lam al-Nubala'. Beirut: Muassasah al-Risalah Al-Dusuqi, M. (n.d.). al-ljtihad fi al-Fiqh al-Islami. Qaherah: al-Majlis al-A'la li Shu'un al-Islamiyyah Al-Fahri, I. F. (2001). Mafhum al-ljma’ 'inda al-Imam al-Shafi`i, Dirasah Mustalahiyyah. Qaherah: Dar al-Salam

Al-Ghazali, M. M. (1997). al-Mustasfa fi ‘llm al-Usul. Beirut: Muassasah al-Risalah Al-Humawi, Y. A. (n.d.). Mu'jam al-Buldan. Beirut: Dar al-Fikr Al-Husayn, W. A. (2009). I'tibar Ma'alat al-Af'al wa Atharuha al-Fiqhi. Riyad: Dar al-Tadmuriyyah Al-Juwaini, A. M. A. (1997). al-Burhan fi Usul al-Fiqh. Beirut: Dar al-Kutub al-'Ilmiyyah Al-Manjur, A. A. (n. d.). Sharh al-Manhaj al-Muntakhab. Riyad: Dar al-Shanqiti Al-Mawardi, A. M. H. (1986). al-Ahkam al-Sultaniyyah. Kuwait: Maktabah Dar Ibn Qutaibah Al-Muhamid, S. A. H. (2001). Masirah al-Figh al-Islami al-Mu'asir. Urdun: Dar 'Ammar Al-Muraghi, M. M. (2011). al-ljtihad fi al-Islam. Jiddah: Maktabah Kunuz al-Ma'rifah Al-Nadwi, A. A. (2009). al-Qawa'id al-Fiqhiyyah. Dimashq: Dar al-Qalam Al-Qaradawi, Y. (1996). Fiqh al-Awlawiyyat. Qaherah: Maktabah Wahbah 
INTERNATIONAL JOURNAL OF ACADEMIC RESEARCH IN BUSINESS AND SOCIAL SCIENCES

Vol. 8, No. 7, July 2018, E-ISSN: 2222-6990 @ 2018 HRMARS

Al-Qaradawi, Y. (2004). Sanggahan Salah Tafsiran Islam, Translated by Abdul Rahman Rukaini. Kajang: Synergymate Sdn. Bhd

Al-Qaradawi, Y. (2011). Madkhal li Dirasah al-Shari'ah al-Islamiyyah. Qaherah: Maktabah Wahbah

Al-Qasimi, J. (1406H). al-Fatwa fi al-Islam. Beirut: Dar al-Kutub al-'Ilmiyyah

Al-Qayyim, M. A. (1973). I'lam al-Muwaqqi'in 'an Rabb al-'Alamin. Beirut: Dar al-Jil

Al-Qurtubi, M. A. (n.d.). al-Jami' li Ahkam al-Qur'an. Qaherah: al-Hai'ah al-Misriyyah

Al-Risa', M. A. (1993). Sharh Hudud Ibn 'Urfah. Beirut: Dar al-Gharb al-Islami

Al-Shahid, A. A. (2005). Hujjah Allah al-Balighah. Beirut: Dar al-Jil

Al-Shatibi, I. M. (1997). al-Muwafaqat. Sa'udi: Dar Ibn ‘Affan

Al-Shaukani, M. A. (1396H). Al-Qawl al-Mufid fi Adillah al-ljtihad wa al-Taqlid. Kuwait: Dar al-Qalam

Al-Shaukani, M. A. (1999). Irshad al-Fuhul ila Tahqiq al-Haq min 'Ilm al-Usul. Beirut: Dar al-Kitab al'Arabi

Al-Shikh, M. A. S. (2002). Mura'ah al-Khilaf fi al-Madhahib al-Maliki. Dubai: Dar al-Buhuth

Al-Subki, T. A. (1991). al-Asybah wa al-Nazair. Beirut: Dar al-Kutub al-'Ilmiyyah

Al-Tha'alabi, M. H. (2012). al-Fikr al-Sami fi Tarikh al-Figh al-Islami. Beirut: al-Maktabah al-'Asriyyah

Al-Yusof, S. S. (1430H). al-ljtihad la Yanqudu bi al-ljtihad, dirasah ta'siliyyah wa tatbiqiyyah. Majallah al-'Adl, 44, h. $18-70$

Al-Zarqa', M. (1995). Sharh al-Qawa'id al-Fiqhiyyah. Dimashq: Dar al-Qalam

Al-Zarqa', M. A. (1999). Fatawa. Dimashq: Dar al-Qalam

Al-Zuhaili, W. (2014). Juhud Taqnin al-Fiqh al-Islami. Dimashq: Dar al-Fikr

Asni, F. A. H. M. (2016a). Fatwa Tentang Pindah Milik Harta: Kajian Terhadap Penyeragamannya Di Malaysia. Masters Dissertation. Universiti Sains Malaysia.

Asni, F. A. H. M. (2017). Al-Syatibi Methodology Analysis in the Unification of Usul Al-Figh Methods. International Journal of Academic Research in Business and Social Sciences, 7(7), 260-268.

Asni, M. F. A. H. M., \& Sulong, J. (2017). Standardisation of Fatwa Regarding Waqf Issues in Malaysia: A Literature Review. Journal of Fatwa Management and Research, 9(1), 110-128.

Asni, M. F. A. H. M., \& Sulong, J. (2016b). Fatwa Berhubung Wasiat Wajibah Dan Keseragaman Peruntukannya Dalam Fatwa Negeri-Negeri Di Malaysia. Al-Qanatir International Journal of Islamic Studies, 5(1), 1 - 15.

Asni, M. F. A. H. M., \& Sulong, J. (2017). Fatwa Coordination between States: Analysis Of The Practices Of Standardization And Its Method In Malaysia. Journal of Fatwa Management and Research, 9(1), 86-109.

El-Muhammady, A. H. (1992). Ikhtilaf and its development in Malaysia. International Islamic University Law Journal, 2(2), 54-55.

Ibn 'Abidin, M. A (1386H). Raddu Al-Mukhtar 'Ala Al-Durri Al-Mukhtar. Beirut: Dar al-Fikr Jaddiyyah, U. (2010). Asl I'tibar al-Maal baina al-Nazariyyah wa al-Tatbiq. Beirut: Dar Ibn Hazm Kathir, I. U. (1988). al-Bidayah wa al-Nihayah. Beirut: Dar Ihya' al-Turath al-'Arabi

Khudzri, W. A. R. (2006). Analisis Penggunaan Kaedah Istinbat Dalam Penetapan Fatwa Di Malaysia: Kajian Di Jabatan-Jabatan Mufti Terpilih. PhD Dissertation, Department of Islamic Studies, School of Humanities, USM.

Malik, M. (2005). Talfiq: Mengamal Pelbagai Mazhab. Selangor: Karya Bestari

Mamat, Z., Mohamad, M. N., \& Hashim, H. (2013). Pengurusan muzakarah Jawatankuasa Fatwa Majlis Kebangsaan dan Jawatankuasa Fatwa Negeri: Satu analisis persamaan dan perbezaan fatwa tahun 2000-2009. International Journal of Management Studies (IJMS), 20(2), 145-166.

Manzur, M. M. (n.d.). Lisan al-'Arab. Beirut: Dar al-Sadir 
INTERNATIONAL JOURNAL OF ACADEMIC RESEARCH IN BUSINESS AND SOCIAL SCIENCES

Vol. 8, No. 7, July 2018, E-ISSN: 2222-6990 @ 2018 HRMARS

Mohamad, M. N., \& Mamat, Z. (2014). Penerimaan dan Penyelarasan Fatwa Muzakarah Jawatankuasa Fatwa Majlis Kebangsaan Bagi Hal Ehwal Ugama Islam Malaysia oleh NegeriNegeri. Journal of Fatwa Management and Research, 4, 33-66.

Musa, A. Q. I. (1983). Tartib al-Madarik wa Taqrib al-Masalik. al-Maghrib: Wizarah al-Awqaf wa alShu'un al-Islamiyyah

Musa, S. M. (n.d.). al-ljtihad wa Mada Hajatuna fi Hadha al-'Asr. Qaherah: Dar al-Kutub al-Hadithah Naemah Abd Rahman. (2003). Fatwa Jemaah Ulamak Kelantan Tahun 1920an Hingga 1990an: Satu Analisis. PhD Dissertation, Department Fiqh and Usul, School of Islamic Studies Universiti Malaya

Nasohah, Z., Laluddin, H., Kusrin, Z. M., \& Muwazir, R. (2012). Standardisation of fatwa in Malaysia: management and problems. Advances in Natural and Applied Sciences, 6(6), 923-930.

Shaqrun. M. A. (2002). Mura'ah al-Khilaf 'Inda al-Malikiyyah wa Atharuhu fi al-Furu' al-Fiqhiyyah. Dubai: Dar al-Buhuth li al-Dirasat al-Islamiyyah

Sulong, J. (2014). Pemikiran Epistemologi IlmuAbd Allah Ibn al-Muqaffa' dalam Penyeragaman Undang-Undang: Pengaruhnya di Malaysia. Jurnal Akidah \& Pemikiran Islam, 97-130.

Zaidan, A. K. (2003). al-Madkhal li Dirasah al-Shari'ah al-Islamiyyah. Beirut: Muassasah al-Risalah 